\title{
EFFECT OF CORPORATE GOVERNANCE ON FINANCIAL PERFORMANCE OF LISTED DEPOSIT MONEY BANKS IN NIGERIA
}

JOSHUA, UDEMEOBONG MONDAY, EFIONG, EME JOEL AND IMONG, NELLY RAPHEAL

(Received 11 June 2019, Revision Accepted 9 July 2019)

\begin{abstract}
This study examined corporate governance and financial performance of listed deposit money banks (DMBs) in Nigeria. The study covered listed DMBs listed in the Nigerian Stock Exchange (NSE) for a ten year period from 2007-2016 and data were obtained from their annual financial reports. Data were presented using tables and analyzed using panel data regression. The corporate governance mechanisms of board size (BSIZE), board composition (BCOM) and audit committee (ACOM) were used as independent variables. Performance of the listed DMBs was measured by return on asset (ROA) which is the dependent variable while the bank size (FSIZE) was used as a control variable.The findings of this study revealed that board size had a positive but insignificant relationship with performance. It was also observed that audit committee, board composition and bank size all had positive and significant relationships with return on asset. The study therefore concludes that board composition and audit committee are good predictors of performance as measured by return on assets (ROA). The study recommended that DMBs listed in the Nigerian Stock Exchange should strive to have an average of fourteen members in their boards to avoid decision-making problems which are characterized by larger board of directors and should therefore comprise a mix of executive and nonexecutive directors with the relevant credentials, competence, and experience to serve on the board of banks. Additionally, the audit committee of banks should meet often to enable them review the financial reports of the banks and make appropriate recommendations that will help to improve the performance of the banks.
\end{abstract}

KEYWORDS: corporate governance, financial performance, board size, board composition and audit committee.

\section{INTRODUCTION}

Corporate governance in recent times has attracted a good deal of public interest because of its great importance to the financial and economic growth of corporations and the society in general. The growing need for strong corporate governance has been very crucial with countries around the world drawing up guidelines and codes of practice to strengthen governance
(Cadbury, 1992, Corporate Governance Code of Nigeria, 2006). The underlying reason for this growing interest is the increased concerns over the integrity of these securities markets in both developed and developing countries. In the Nigerian scene, the case of Cadbury Nigeria PLC who manipulated their stock position to deceive shareholders, NAMPAK, as well as Wema Bank, Afribank, Finbank, and Springbank shook the confidence of investors and regulators alike. The

Joshua, Udemeobong Monday, Department of Accounting University of Calabar, Calabar, Nigeria.

Efiong, Eme Joel, Department of Accounting University of Calabar, Calabar, Nigeria.

Imong, Nelly Rapheal, Department of Accounting University of Calabar, Calabar, Nigeria.

(C) 2019 Bachudo Science Co. Ltd. This work is licensed under Creative Commons Attribution 4.0 International license. 
banking sector has also suffered its fair sphere of scandals and distress where seemingly healthy banks suddenly collapsed and these have made investors confidence to be shaken. Corporate governance is a key-element in the development and establishment of capital market's of nations. The World Bank Report - Improving Corporate Governance in Emerging Markets (2011) asserts that good corporate governance reduces the emerging markets' vulnerability associated to financial crisis, reduces transactions and capital cost and, contributes to the development of capital markets.

The banking distress of the last decades has posed many challenges to corporate governance in banking industry. Bank distress can be associated to lack or avoidance of code of ethics and professionalism. Odozi (2007) asserts that "Ethics, like, corporate governance, transparency and accountability, etc, is a cliché that has been abused and misused". The failure of banks in Nigeria, as well as across the globe has been largely due to inadequate corporate governance. This has necessitated the apex bank (Central Bank of Nigeria) to take a bold step in revitalizing the banking sector since corporate governance had become a subject of major concern by all sectors of the economy. The Nigerian Securities and Exchange Commission (SEC) rolled out a code of best practices on corporate governance for all public quoted companies in 2003. As a result, the Peterside Committee on corporate governance in public companies was set up to check the corporate governance of these companies. A sub-committee on corporate governance for banks and other financial institutions in Nigeria was set up by the Bankers' Committee. The Central Bank of Nigeria (CBN) code of corporate governance for banks was also issued in 2006 by the apex bank to help in achieving viable and successful banking practice along with the existing codes that were in place. All of this is in recognition of the critical role of corporate governance in the success or failure of companies (Ogbechie, 2006:6). Since the issuance of the code of corporate governance by the CBN, efforts have been made to evaluate its impact on the performance of banks.

\subsection{Statement of the problem}

The banking sector has a distinct role in facilitating and stimulating economic development as it plays a vital role in the resource mobilization and allocation of the economy. This is the most important part of the financial system in developing economies as the banks account for the bulk of the financial transactions and assets. Banks are the main pillar of the financial system in most countries as banks provide different opportunity and services to clients. The banking sector is of immense importance in the progress and richness of any state. The economic development and prosperity comes from the well developed and perfect banking system. It is believed that banks occupy an important position in the economic health of any country such that its (good or poor) performance invariably affects the economy of the country. In Nigeria, bank plays a significant and sensitive role in the economy hence their performance affects the growth, competence and stability of the economy directly. The failure rate of banks can be attributed to poor corporate governance and this can lead to investors losing confidence in the ability of a bank to properly manage its assets and liabilities, which could in turn trigger liquidity crisis. Recent financial crisis across the world has had banks and other financial intermediaries at the heart of this major crisis. As a result of these, various corporate governance reforms and codes have been introduced to ease governance with the mechanisms of board size, board composition, and audit committee as core amongst others. The board size is believed to enhance performance of firms especially where its composition is made of outside directors as it has a positive and significant effect on the bank performance. The code of corporate governance emphasizes board composition that has qualitative, qualified, experienced members and people of proven integrity to serve on the board.

Despite all these measures, the problem of corporate governance still remains unresolved among the consolidated Nigerian banks, thereby increasing the level of financial reporting scandals and fraudulent information disclosures in the banking industry as seen in the series of publicized cases of accounting inappropriateness recorded in banks such as Intercontinental bank, Oceanic bank, Afri bank, Fin bank and Spring bank. Most of this is related to lack of vigilant oversight functions by the board of directors and this shook the confidence of investors. Previous researches were inadequate looking at the sample size and number of years, also their measurement of audit committee was based on the audit committee size and its composition. There is therefore a need to increase the number of years and sample size and to use a different measure for the audit committee. On the basis of this foregoing, this study examines the effect of 
corporate governance on the financial performance of listed deposit money banks in Nigeria.

\subsection{Objectives of the study}

Generally, this study looked corporate governance and financial performance of listed deposit money banks in Nigeria. . However, the specific objectives of the study were to:

i) Examine the effect of board size on the financial performance of listed deposit money banks in Nigeria.

ii) Ascertain the effect of board composition on the financial performance of listed deposit money banks in Nigeria.

iii) Assess the influence of audit committee on the financial performance of listed deposit money banks in Nigeria.

iv) Examine the effect of bank size on the financial performance of listed deposit money banks in Nigeria.

\subsection{Research questions}

The following research questions were formulated to guide the study:

i) To what extent does board size affect the financial performance of listed deposit money banks in Nigeria?

ii) To what extent does board composition affect the financial performance of listed deposit money banks in Nigeria?

iii) Does audit committee influence the financial performance of listed deposit money banks in Nigeria?

iv) To what extent does bank size affect the financial performance of listed deposit money banks in Nigeria?

\subsection{Research Hypotheses}

To proffer useful answers to the research questions, the following hypotheses stated in their null forms;

$\mathrm{H}_{0} 1$ : There is no significant relationship between board size and financial performance (Return on Assets) of listed deposit money banks in Nigeria.

$\mathrm{H}_{0}$ 2: $\quad$ Board composition has no significant relationship with financial performance (Return on Assets) of listed deposit money banks in Nigeria.

$\mathrm{H}_{0} 3$ : There is no significant relationship between audit committee and financial performance (Return on Assets) of listed deposit money banks in Nigeria.
$\mathrm{H}_{0} 4$ : There is no significant relationship between bank size and financial performance (Return on Assets) of listed deposit money banks in Nigeria.

\section{LITERATURE REVIEW AND THEORETICAL FRAMEWORK}

\section{$2.1 \quad$ Theoretical framework}

The theories underlying this study are the agency theory and the resource dependency theory.

\subsubsection{Agency theory by Jensen and Meckling (1976)}

Agency theory as propounded by Jensen and Meckling (1976), opened the important research area concerning the separation of ownership and control in the modern corporation and it defines the agency relationship as a contract in which one or more persons usually known as the 'principal' engages another person known as the agent to perform some service on their behalf, which involves delegating some decision-making authority to the agent. Haslinder and Benedict (2009) define the agency theory as "the relationship between the principals, such as the shareholder and agents such as the company executives and managers". This theory seeks to explain the problem that arises from the separation of ownership and control. The conflict of interests between managers and the principals refer to the tendency that the former may become self-interested and opportunistic in the course of doing business. However, the principal can counter such problems by incurring agency costs which include monitoring expenditures such as auditing, budgeting. The share price that shareholders (principal) pay reflects such agency costs. To increase firm value, one must therefore reduce agency costs. This is one way to view the linkage between corporate governance and corporate performance. The agency theory prescribes strong director and shareholder control. It advocates that the fundamental function of the board of directors is to control managerial behavior and ensure that managers act in the interests of shareholders.

\subsubsection{Resource Dependency Theory by Pfeffer (1978)}

Whilst the stakeholder theory focuses on relationships with many groups for individual benefits, resource dependency theory by pfeffer (1978), concentrates on the role of board directors in providing access to resources needed by the firm (Abdullah \& Valentine, 2009). 
According to this theory the primary function of the board of directors is to provide resources to the firm. Directors are viewed as an important resource to the firm. When directors are considered as resource providers, various dimensions of director diversity clearly become important such as gender, experience, qualification and the like. According to Abdullah and Valentine (2009), directors bring resources to the firm, such as information, skills, business expertise, access to key constituents such as suppliers, buyers, public policy makers, social groups as well as legitimacy. Boards of directors provide expertise, skills, information and potential linkage with environment for firms. The resource based approach notes that the board of directors could support the management in areas where technical knowledge is limited. Wang (2009) believes that the resource dependence model shows that the board of directors could be used as a mechanism to form links with the external environment in order to support the management in the achievement of organizational goals. While the agency theory concentrates on the monitoring and controlling role of board of directors, there resource dependency theory sheds more light on the advisory and counseling role of directors to a firm management.

\subsection{Conceptual framework}

\subsubsection{Meaning of Corporate Governance}

Corporate governance is a uniquely complex and multi-faceted subject. It is an important concept which has attracted a fairly good deal of public interest because of its great importance for the financial and economic health of corporations and society in general. It has no single accepted definition mainly due to the huge differences in countries corporate governance codes (Solomon, 2010). As such it is essential that a comprehensive framework be codified in the accounting framework of any organization. In any organization, corporate governance is one of the key factors that determine the health of the system and its ability to survive economic shocks. The aim of corporate governance is to ensure that corporations are managed in the best interest of their owners and shareholders. (Ahmed, Alam, Jafar and Zaman, 2008).

According to Morck, Shleifer and Vishny (1989), corporate governance along with other factors such as effective marketing discipline, strong prudential regulation and supervision, accurate and reliable accounting financial reporting systems, are the main factors that support the stability of any country's financial system. Efiong and Crowther (2012), presented a study on the enforcement of accountability in public governance in Africa. The study opined that accountability in public is vital.

Literature is satiated with various views and definitions of corporate governance (CG) (Cadbury 1992; Organization for Economic Cooperation and Development (OECD) 1996; Shleifer and Vishny 1997; Kwakwa and Nzekwu (2003). There is however no consensus on the definition of corporate governance, may be due to the fact that the concept is applied across disciplines including management, law, behavioral sciences and even humanities (Adelopo 2010).

Governance itself relates to the decisions of any organization where expectations are defined, power granted to actualize the expectations and performance evaluated at the end. Cadbury (1992) defined corporate governance as "the set of process" customs, policies, laws and institutions affecting the way a corporation company is directed, administered or controlled". It is the way the boards oversee the running of a company by its managers, and how board members are held accountable to shareholders of the company, with implications also to employees, customers, stakeholders, etc. It therefore suggests that corporate governance "is concerned with holding the balance between economic and social and between individual and communal goals" (Adelopo 2010, p. 17). Corporate governance also includes the relationships among the many stakeholders involved and the goals that govern the corporation (OECD, 2004).

\subsubsection{Concept of Consolidation and Corporate Governance of Banks}

The banking industry in Nigeria has gone through various stages of restructuring. Consolidation in the banking sector began in 2004 when the CBN mandated all commercial banks to meet the N25 billion minimum paid-up capitals by 31 st December, 2005. These directives saw the banks using various mechanisms to comply with the apex bank's mandate. Some of the banks used these methods to comply with the apex bank's directive which includes mergers and acquisition, initial public offerings (IPOs), foreign equity participation, group consolidation etc. (Orji, 2005). Almost all the banks went to the capital market to raise funds in order to meet the new capital base. Al Faki (2006) as sited in Donwa and Odia (2011) puts the figure that was raised from the capital market by the banks to meet the 
minimum capital requirement of N25billion as over N406.4 billion. Out of the N198.19 billion worth of securities raised in 2004, N128.58 billion was for the banking sector. In 2005, banks' new issues were worth N517.6 billion. This amount represented about $75 \%$ of the total new issues value of N692.86 billion.

The banking sector reform and its subcomponent, bank consolidation, have resulted from deliberate policy response to correct perceived or impending banking sector crises and subsequent failures. Uchendu (2005) as cited by Abdullahi (2007) opined that banking crisis can be triggered by the dominant influence of weak banks characterized by persistent illiquidity, insolvency, under capitalization, high level of nonperforming loans and weak corporate governance among others, as observed in the Nigeria case.

\subsubsection{Financial performance}

Financial performance assesses the fulfillment of a firms economic goal and this relates to various subjective measure of how well a firm can use its given assets from primary mode of operation to generate profit. Financial performance has long been an issue of interest in managerial discussion. Kothari (2001) defined the value of a firm as the present value of the expected future cash flows after adjusting for risk at an appropriate rate of return.

Bank performance is usually measured by ROA, ROE or NIM. Studies conducted on the determinants of banks performance use one or a combination of these ratios as a measure of performance in their analysis. This study examines the most comprehensive accounting measure of a bank's overall performance which is Return on assets (ROA).

\subsubsection{Measurement of Bank Sector Reforms and Deposit Money Banks Performance.}

The banking sector reforms is a vital tool in assessing the performance of deposit money banks and this is extremely important because it helps to assess if the policy is well designed and implemented. There is a positive relationship between financial sector reforms and the performance of the deposit money banks as argued by many researchers. This can be measured using specific key indicators and this also applies to the Nigerian deposit money banks. The financial sector indicators are many, but we limited our consideration to the major indicator Returns on Assets (ROA) of deposit money banks.
The various reforms have yielded the anticipated result as the new policy initiative will influence both the economy as well as the banking system as observed by Ogunleye (2005). Efforts of banks to comply with the new consolidation policy helps to strengthen corporate governance in banks in order to boost public confidence and ensure efficient and effective functioning of the banking system on the effect of small business. Merger and acquisition has been identified as one of the instruments of recent banking reforms in Nigeria as opined by Emeni and Okafor (2008) and they used cross sectional survey research and ordinary least square regression analysis to draw this conclusion. Their results showed the two effects of merger and acquisition as static effect and dynamic effect.

\subsubsection{Recapitalization in banks}

Recapitalization is a major reform objective which has to do with increasing the amount of long term finances used in financing an organization. It entails increasing the debt stock of the company or issuing additional shares through existing shareholders or new shareholders or a combination of the two. Merger and acquisition or foreign direct investment are examples of the forms of recapitalization and the end result is that the long term capital stock of the organization is increased substantially to sustain the current economy trend in the global world not minding whichever form is being used. Soludo (2004) asserts that low capitalization of the banks has made them less able to finance the economy, and more prone to unethical and unprofessional practices.

\subsection{Empirical review}

Grove, Patelli, Victoravich, and Xu (2011) carried out an empirical study on "Corporate governance and performance in the wake of the financial crisis: Evidence from US commercial banks". The objective of the study was to examine if corporate governance will explain US bank performance during the period leading up to the financial crisis? They adopted the factor structure by Larcker, Richardson, and Tuna (2007) to measure multiple dimensions of corporate governance for 236 public commercial banks. Research Findings/Insights from their study revealed that corporate governance factors explain financial performance better than loan quality. They also found strong support for negative association between leverage and both financial performance and loan quality. Findings 
also showed a concave relationship between financial performance and both board size.

A study on the Determinants of Financial Performance: An Empirical Study on Ethiopian Commercial Banks was carried out by Abebe (2014). The study examined the determinants of financial performance of commercial banks in Ethiopia using panel data of banks over the period 2002-2013. Under this study, both internal and external factors were included. The internal factors used in this study included capital structure; Income Diversification, operating cost and bank size whereas the external factors are effective tax rate, real GDP growth and inflation. Moreover, ROA and NIM were used as the performance measure. The regression result showed that the bank specific variables except bank size affect performance of the bank significantly but negatively. Also, bank size affects performance significantly and positively. In another linked study, Kent and Stewart (2008) presented a study on corporate governance and disclosures on the transition to International Financial Reporting Standards using a sample of listed Australian companies. Results from their findings showed that the quality of disclosure was positively related to corporate governance mechanisms such as frequency of board and audit committee meeting.

Ahmed and Hamdan (2015) carried out an investigation on the impact of corporate governance on firm performance: evidence from Bahrain stock exchange. The aim of this research was to examine the impact of corporate governance characteristics on firm performance in Bahrain Stock Exchange. Their study sampled 42 Out of 48 Bahrain's financial companies which are listed in Bahrain Stock Exchange during the period 2007-2011. The empirical results from their study indicates that performance measures such as Return on Assets and Return on Equity are significantly related to corporate governance in Bahrain. On the whole, their study found a positive influence of corporate governance mechanisms on performance for the entire firms in Bahrain Stock Exchange.

Hajer and Anis (2016) carried out a study on the analysis of the impact of governance on bank performance: case of commercial Tunisian banks. Their empirical analysis was on a sample of eight Tunisian commercial banks listed on the Stock Exchange over the period 2000-2011; findings from their work concluded that there is no standard governance structure and that each bank should adopt the appropriate governance structure to improve the performance of the financial market, in general, and the banking market, in particular.

Onakoya, Ofoegbu, and Fasanya, (2010) examined the impact of corporate governance on bank performance in Nigeria during the period 2005 to 2009 based on a sample of six selected major banks in Nigeria \{First Bank of Nigeria Plc, United Bank of Africa (UBA), Eco Bank, Fidelity Bank, First City Monument Bank (FCMB), and Guarantee Trust Bank (GTB)\} in the post consolidation era- 2005 to 2009 as listed on Nigerian Stock Exchange market making use of pooled time series data. From their findings, it was shown that corporate governance has been on the low side and has impacted negatively on bank performance.

Ifionu and Keremah (2016) investigated the impact of banking reforms on the performance of Deposit Money Banks in Nigeria spanning from 1995 to 2012. Their study reveals that Return on Equity and banks profitability have a significant difference in the pre and post bank reform era while Return on Assets shows that there is no significant difference in the pre and post banking reform era in Nigeria. Thus, the study reached a consensus that the improved level of Deposit Money Bank profitability is associated to the various bank reforms in Nigeria especially the adoption of corporate governance codes.

\subsection{Research Methodology}

The research design employed in this study is the ex-post facto design.

The population of this study comprises of all the 15 listed commercial banks listed in the Nigerian Stock Exchange. The research was limited to accessible population of the listed commercial banks because of the availability of data from Nigeria Stock Exchange (NSE) as well as the fact book. The study adopted the census approach as it was unnecessary for sampling or sample size determination. Data used in the study were extracted from corporate financial statements and annual reports of the banks submitted to the NSE. The data covered a period of ten years from 2007 to 2016 . The listed banks are indicated in the table below: 


\section{TABLE 3.1}

\section{Listed banks in Nigeria}

\begin{tabular}{llc}
\hline S/N & Banks & Year of Listing \\
\hline 1. & Access Bank Plc & 1998 \\
2. & Diamond Bank Plc & 2005 \\
3. & EcobankPlc Plc & 2006 \\
4. & Fidelity Bank Plc & 2005 \\
5. & First Bank Plc & 1971 \\
6. & First City Monument Bank (FCMB) Plc & 2004 \\
7. & Guaranty Trust Bank (GTB) Plc & 1996 \\
8. & Skye Bank Plc & 2005 \\
9. & Stanbic IBTC Plc & 2005 \\
10. & Sterling Bank Plc & 1993 \\
11. & Union Bank Plc & 1970 \\
12. & United Bank For Africa (UBA) PLC & 1970 \\
13. & Unity Bank Plc & 2005 \\
14. & Wema Bank Plc & 1991 \\
15. & Zenith Bank Plc & 2004 \\
\end{tabular}

Source: Nigeria Stock Exchange Listed Banks 2015

The main source of data is secondary data from the annual reports and financial statements of the listed commercial banks for ten year period from 2007- 2016. The model that is adopted for this study is the multiple regression models to examine the combined effect of board size, board composition audit committee, and firm size on the performance of listed commercial banks in Nigeria. The model is specified below:

Performance $=f(B S I Z E, B C O M, A C O M$, FSIZE $)$

$\mathrm{ROA}=\beta_{\mathrm{o}}+\beta_{1} \mathrm{BSIZE}+\beta_{2} \mathrm{BCOM}+\beta_{3} \mathrm{ACOM}+\beta_{4}$ FSIZE $+e_{t}$

Where:

ROA represents a firm performance variable which is Return on Asset

BSIZE $=$ Board size
$\mathrm{BCOM}=$ Board composition

ACOM= Audit committee

FSIZE = Bank Size

$\beta_{\circ}$ to $\beta_{5}=$ Coefficient

$e_{t}=$ Stochastic error term. The error term which account for other possible factors that could influence ROA that are not captured in the model The a priori is such that:

$\beta_{1}, \beta_{2}, \beta_{3}, \beta_{4}>0$. The implication of this is that a positive relationship is expected between explanatory variables $\left(\beta_{1} ; \beta_{2} ; \beta_{3} ; \beta_{4}\right)$ and the dependent variable (ROA). The size of the coefficient of correlation will help us explain various levels of relationship between the explanatory variables. 
TABLE 3.2a

Cross sectional result showing impact of corporate administration on money related execution of the recorded banks in Nigeria.

Coefficients of listed banks

\begin{tabular}{lllllllll}
\hline Variables & Access & Diamond & Ecobank & FCMB & Fidelity & $\begin{array}{l}\text { First } \\
\text { bank }\end{array}$ & GTB & Skye \\
\hline BSIZE & 2.1337 & -0.1790 & 0.0945 & -0.4193 & -0.0676 & -0.0368 & 0.4779 & -0.2055 \\
& $(-4.46)$ & $(4.32)$ & $(4.38)$ & $(5.60)$ & $(3.84)$ & $(-0.33)$ & $(9.57)$ & $(-3.07)$ \\
& 0.6627 & 0.0760 & 0.0000 & 0.0025 & 0.0046 & 0.0077 & 0.0823 & 0.0419 \\
& & & & & & & & \\
BCOM & 1.9832 & -12.1801 & 1.3381 & 1.4858 & -1.2642 & 3.6116 & -0.8427 & 0.4152 \\
& $(6.80)$ & $(2.80)$ & $(6.18)$ & $(2.18)$ & $(2.71)$ & $(2.84)$ & $(3.17)$ & $(1.13)$ \\
& 0.4516 & 0.0104 & 0.0000 & 0.0077 & 0.0078 & 0.0091 & 0.0069 & 0.0075 \\
ACOM & 1.6641 & 0.3109 & 0.1748 & 0.0104 & 0.8337 & 1.1901 & -0.3329 & 0.2905 \\
& $(4.71)$ & $(3.20)$ & $(2.20)$ & $(1.00)$ & $(1.05)$ & $(4.56)$ & $(2.40)$ & $(5.26)$ \\
& 0.2879 & 0.0999 & 0.0000 & 0.0974 & 0.0382 & 0.0004 & 0.0015 & 0.0037 \\
FSIZE & 4.2700 & 1.2802 & -1.3420 & 2.0038 & -1.1285 & 0.5860 & 0.5146 & 1.6352 \\
& $(8.90)$ & $(8.09)$ & $(-5.20)$ & $(2.09)$ & $(1.81)$ & $(2.91)$ & $(1.74)$ & $(2.80)$ \\
& 0.4088 & 0.0308 & 0.0000 & 0.0964 & 0.0048 & 0.0171 & 0.0681 & 0.0568 \\
R & 0.83 & 0.59 & 0.83 & 0.52 & 0.84 & 0.62 & 0.50 & 0.72 \\
SER & 0.73 & 4.00 & 0.09 & 0.018 & 0.33 & 0.26 & 0.20 & 0.34
\end{tabular}

Note: The values in bracket show the respective T-statistics of the variable coefficients. And the figures below the T-statistics show the P-values of each variable.

Source: Author's compilation from panel regression

TABLE 3.2b

Cross sectional result showing impact of corporate administration on money related execution of the recorded banks in Nigeria (cont.d).

Coefficients of listed banks

\begin{tabular}{llllllll}
\hline Variables & Stanbic & $\begin{array}{l}\text { Sterling } \\
\text { bank }\end{array}$ & UBA & $\begin{array}{l}\text { Union } \\
\text { Bank }\end{array}$ & $\begin{array}{l}\text { Unity } \\
\text { Bank }\end{array}$ & $\begin{array}{l}\text { Wema } \\
\text { Bank }\end{array}$ & $\begin{array}{l}\text { Zenith } \\
\text { Bank }\end{array}$ \\
\hline BSIZE & 1.3588 & 0.0230 & 0.0296 & -4.7604 & -1.3011 & -1.8891 & 0.131 \\
& $(3.89)$ & $(5.04)$ & $(2.07)$ & $(-6.87)$ & $(-6.62)$ & $(2.64)$ & $(3.27)$ \\
& 0.0114 & 0.0220 & 0.0407 & 0.0091 & 0.0571 & 0.0061 & 0.0924 \\
BCOM & 1.1726 & 0.7842 & 1.0928 & 2.0668 & 1.0370 & 0.0875 & -2.4777 \\
& $(3.34)$ & $(2.01)$ & $(4.76)$ & $(4.64)$ & $(3.53)$ & $(1.96)$ & $(6.02)$ \\
& 0.0204 & 0.0006 & 0.0763 & 0.0171 & 0.0167 & 0.1068 & 0.0029 \\
ACOM & 2.9678 & 1.3910 & 0.7161 & 0.8020 & 0.2284 & 1.0153 & -0.5033 \\
& $(4.05)$ & $(2.8)$ & $(8.77)$ & $(3.12)$ & $(5.22)$ & $(5.65)$ & $(5.50)$ \\
& 0.0097 & 0.0104 & 0.0713 & 0.0032 & 0.0011 & 0.0024 & 0.0953 \\
FSIZE & 2.3271 & 1.0526 & -4.7413 & 1.1632 & 1.6702 & -2.9503 & 4.8141 \\
& $(4.57)$ & $(1.40)$ & $(-5.28)$ & $(5.40)$ & $(4.17)$ & $(1.84)$ & $(8.65)$ \\
& 0.0059 & 0.0000 & 0.0790 & 0.0523 & 0.0041 & 0.0137 & 0.0405 \\
$\mathbf{R}^{2}$ & 0.75 & 0.58 & 0.53 & 0.52 & 0.53 & 0.90 & 0.62 \\
SER & 0.05 & 0.05 & 0.04 & 0.06 & 0.06 & 0.20 & 0.23
\end{tabular}

Note: The values in bracket show the respective T-statistics of the variable coefficients. And the figures below the T-statistics show the P-values of each variable. Source: Author's compilation from panel regression. 
POOLED REGRESSION

SUMMARY OUTPUT

\begin{tabular}{ll}
\hline \multicolumn{2}{l}{ Regression } \\
\hline Multiple R & 0.284691 \\
R Square & 0.61049 \\
Adjusted R & \\
Square & 0.55699 \\
Standard & \\
Error & 5.20383 \\
Observations & 150 \\
\hline
\end{tabular}

\begin{tabular}{lllll} 
ANOVA & \multicolumn{5}{l}{} \\
& df & SS & MS & F \\
\hline Regression & 4 & 346.3145 & 86.57862 & 3.19716 \\
Residual & 145 & 3926.578 & 27.07985 & \\
Total & 149 & 4272.893 & & \\
\hline \multicolumn{5}{c}{} \\
\hline \multicolumn{5}{c}{ Standard } \\
C & Coefficients & Error & t Stat & P-value \\
BSIZE & -14.1247 & 0.071227 & 45.78526 & 0.006063 \\
BCOM & 0.123283 & 0.179853 & 2.685463 & 0.094146 \\
ACOM & 1.8976 & 0.45851 & 1.892804 & 0.004407 \\
FSIZE & 1.288349 & 0.534465 & 2.410541 & 0.017181 \\
\hline & 0.674413 & 0.572513 & 1.197063 & 0.033235 \\
\hline
\end{tabular}

Table $3.2 a$ and $3.2 b$ represents cross sectional results of individual bank response of board size (BSIZE), board composition (BCOM), audit committee (ACOM) and firm size (FSIZE). The result indicates that board size (BSIZE) of seven (7) banks viz, Access bank, Ecobank and GTB, Stanbic, Sterling bank, UBA, Zenith bank positively influenced their financial performance. The result further revealed that the financial performance of eleven (11) others banks apart from Diamond, Fidelity, GTB and Zenith banks were positively affected by board composition (BCOM). When we consider the effect of individual bank audit committee (ACOM) on financial performance, we observed that almost all the banks apart from Zenith and GTB banks exerted positive effect on their performance. The outcome also suggests that firm size positively influenced the financial performance of banks.
The results of the pooled regression shows an $\mathrm{R}^{2}$ of 61 per cent and this indicate that the variables BSIZE, BCOM, ACOM and FSIZE which represents board size, board composition, audit committee and firm size jointly explain 61 per cent deviation of banks financial performance while 39 per cent variations in banks financial performance remained unexplained. Moreover, the $\mathrm{R}^{2}$ Adj. of 55 per cent could also be interpreted as joint movement between the banks financial performance and the independent variables.

The constant term ' $C$ ' which is more often called the autonomous coefficient has a value of 14.1247 percent. This result indicates that a decrease of -14.1247 in banks financial performance is bound to occur with or without the existing independent variables and this decrease could be caused by variables outside the model. The value of F-statistics 5.9198 as indicated in 
the result statistically explains variation of the bank's financial performance on corporate governance.

The result indicates that BCOM, ACOM and FSIZE all have a positive significant relationship with return on asset (ROA)as shown in the model with $p$-value $0.0044,0.0171$ and 0.0332 respectively. The pooled panel result lump the independent variables to ascertain the degree of positive changes that occurred between the dependent and explanatory variables.

Audit committee has a positive and significant effect on performance of listed deposit money banks in Nigeria. The coefficient of audit committee from Table 3.3 is 1.288 . This shows a positive relationship with return on asset which is used as a measure of performance in this study. This implies that the more the audit committee of banks meet to review the financial reports and evaluate the internal control systems of the banks, the performance is improved and brings about good more yielded profits. Audit committee meetings should help in checking the activities of managers, as such wrongdoings will be reduced and performance will be enhanced. This result agrees with the findings of Adams and Mehran (2003), Kent and Stewart(2008), and Erena and Tehulu (2012) whose findings revealed that the presence of audit committee and their frequent meetings can reduce financial reporting problems and incidence.

Board composition and firm size however also shows a positive and significant relationship with ROA from the results shown from the pooled regression analysis in table 3.3.

\section{Summary and conclusion}

The findings of this study show that the board size (BSIZE) of seven (7) banks viz, Access Bank, Ecobank, GTB, Stanbic, Sterling Bank, UBA, and Zenith Bank has a positive relationship with their financial performance. However, only Ecobank, Stanbic, Sterling bank and UBA were significant. The result further revealed that the financial performance of eleven (11) others banks apart from Diamond, Fidelity, GTB and Zenith banks were positively affected by board composition (BCOM). Out of the eleven, Ecobank, FCMB, First bank, Stanbic, Sterling, Union, and Unity bank had positive and significant relationship with ROA. When we consider the effect of individual bank audit committee (ACOM) on financial performance, we observed that almost all the banks apart from Zenith and GTB banks exerted positive effect on their performance out of which Ecobank, Fidelity,
First bank, Syke, Stanbic, Union, Unity and Wema banks has positive and significant relationships. . The outcome also suggests that firm size influenced the financial performance of banks positively.

The study also identified from there regression model that board size has a positive but insignificant relationship with performance as measured by return on asset. While the board composition and audit committee had positive and significant relationship with performance. On the whole, corporate governance variables can be seen as having a significant effect on performance of listed DMBS in Nigeria.

\section{REFERENCES}

Abdullahi, I., 2007. Banking sector reforms and bank consolidation in Nigeria: Challenge and prospects.BJMASS,6 (1), 116-125.

Abdullah, H., and Valentine, B. 2009. Fundamental and ethics theories of corporate governance. Middle Eastern Finance and Economics, 4(1), 89-96.

Abebe, T., 2014. Determinants of financial performance: An empirical study on Ethiopian commercial banks. (Master's thesis, Jimma University, Ethopia). Retrieved from https://core.ac.uk/.../pdf/30266978.pdf

Adams, R., and Mehran, H. 2003 .Is corporate governance different for bank holding companies? Economic Policy Review, 9(1), 123-142.

Adelopo, I., 2010. The impact of corporate governance on auditor independence: $A$ study of audit committees in UK listed companies. (Doctoral thesis, De Montfort University).

Ahmed, H., Alam, J., Jafarr, A., and armum, S. 2008. A conceptual review on corporate governance and it effect on firms performance: Bangladesh perspective. AIUB working paper series, No 2008-10, http://orp.aiub.edu/workingpaper,aspx?ye $\mathrm{ar}=2008$

Ahmed, E., and Hamdan, A. 2015. The impact of corporate governance on firm performance: evidence from Bahrain stock exchange. European Journal of 
Business and Innovation Research, 3(5), $25-48$

Al- Faki, M 2006. Transparency and corporate governance for capital market development in Africa: The Nigerian case study. Securities Market Journal, 4, (1), 9- 28.

Cadbury Committee. 1992. Report of the committee on the financial aspects of corporate governance. London: Gee Publishing.

Cadbury, A. 2002. Overview of corporate governance: A framework for implementation. The World Bank Group: Washington. D.C

Central Bank of Nigeria CBN 2006.Code of Corporate Governance for Banks in Nigeria Post Consolidation.

Code of Corporate Governance for Banks and Discount Houses in Nigeria. Effective Date: October 01, 2014. Central Bank of Nigeria CBN Publication.

Donwa, P. And Odia, J. 2011. Effects of consolidation of the banking industry on the Nigerian capital market. Kamla-raj Economics, 2(1), 57-65.

Efiong, E. J @ and Crowther D., 2012. The enforcement of accountability in public governance in Africa. Proceedings of $2^{\text {nd }}$ organizational governance conference Rabat-Morocco, 29-33

Emeni, F. And Okafor, C. 2008.Effect of mergers and acquisition on small business lending in Lagos in Nigeria. Africa Journal of Business Management, 2(9), 325-345

Erena, O. And Tehulu, T. 2012. The Impact of corporate governance mechanisms on earnings management: Evidence from banks in Ethiopia. International Journal of Research in Commerce, Economics and Management, 2(8), 2231-4245.

Grove, H., Patelli, L., Victoravich, L. M., and Xu, P. 2011. Corporate governance and performance in the wake of the financial crisis: Evidence from US commercial banks. Corporate Governance: An International Review, 19(5), 418-436.

Hajer, C., and Anis, J. 2016. Analysis of the impact of governance on bank performance: Case of commercial Tunisian banks. Journal of the Knowledge Economy, 2(1), 255-260.

Ifionu, E. P., and Keremah, S. C. 2016. Bank reforms and deposit money banks performance: evidence from Nigeria. European Journal of Business and Management, 8(7), 136-152.

Jensen, M., and Meckling, W. 1976. Theory of the firm: Managerial behaviour, agency costs and ownership structure. Journal of Financial Economics, 3(4), 305- 360.

Kothari, S. P. 2001. Capital market research in accounting. Journal of Accounting and Economics, 31(2), 105-231.

Kent, P. and Stewart, J. 2008.Corporate governance and disclosures on the transition to international financial reporting standards. Accounting and Finance, 48(2), 647-671.

Kwakwa, A. and Nzekwu, P. 2003. International best practices on corporate governance: Issues in corporate governance, 97(3), 568-576.

Larcker, D., Richardson, S., and Tuna, I., 2007. Corporate governance, accounting outcomes, and organizational performance. The Accounting Review, 4(2), 963-1008.

Morck, R., Shleifer, A. and Vishny, R. 1989.Alternative mechanism for corporate control. American Economic Review, 79(1), 41- 56.

Odozi, V. 2007. Ethics and professionalism in the banking industry: The role of the honorary senior member. The Nigerian Bankers,22(1), 11-16.

OECD 1999. Principles of corporate governance. http://www.encycogov.com/ 
Ogbechie,C. 2006. Corporate governance: A challenge for Nigerian banks. Cited From www. Businessdayonline.com .

Ogunleye, G. 2005. Regulatory challenges in a consolidated Nigeria banking system NDIC.

Onakoya, A., Ofoegbu, D. and Fasanya, I., 2010. Corporate governance and bank performance: a pooled study of selected banks in Nigeria. European Scientific Journal, 8(28), 155-164.

Pfeffer, J. 1972. Size, composition, and function of hospital boards of directors. Administrative Science Quarterly, 18(1), 349-364.
Shleifer, A. and Vishny, R. 1997.A survey of corporate governance. Journal of Finance, 52(2), 737-783.

Solomon, J. 2010. Corporate governance and accountability (3rd ed.). West Sussex: John Wiley and Sons Limited.

Soludo, C. 2004. Consolidating the Nigerian banking industry to meet the development challenges of the 21st century. Being speech presented at the special meeting of bankers committee held at the Central bank of Nigeria $H / Q$, Abuja.

Wang, L. 2009. Corporate governance, industry clustering and corporate performance. The Business Review, 12 (1), 124-189. 